\title{
A Study of Hepatocellular Carcinoma in Chronic Hepatitis C Patients Received Direct Acting Antiviral Drugs
}

\author{
Magdy Abd Elkerim El Dahshan' ${ }^{1}$ MD, Moataz Mostafa Mousa ${ }^{2}{ }^{*}$ MSc., Arafat Abd Elazem Qasem $^{1}$ MD, \\ Wael Refaat Hablas ${ }^{3}$ MD.
}

*Corresponding Author:

Moataz Mostafa Mousa

moataz.mosa.mmmm@gmail.com

Received for publication March 25, 2020; Accepted September 29, 2020; Published online September 29, 2020.

Copyright 2020 The Authors published by Al-Azhar University, Faculty of Medicine, Cairo, Egypt. All rights reserved. This an openaccess article distributed under the legal terms, where it is permissible to download and share the work provided it is properly cited. The work cannot be changed in anyway or used commercially.

doi:10.21608/aimj.2020.26584.1183

${ }^{1}$ Internal Medicine Department, Faculty of Medicine, Al-Azhar University, Cairo, Egypt.

${ }^{2}$ Internal Medicine Department, Dar-elsalam General Hospital, Cairo, Egypt.

${ }^{3}$ Clinical Pathology Department, AlAzhar University, Faculty of Medicine, Al-Azhar University, Cairo, Egypt

\begin{abstract}
Background: Infection with hepatitis $\mathrm{C}$ poses a global health problem that affects 200 million chronically infected patients globally. Infected patients with hepatitis $\mathrm{C}$ virus (HCV) run a high risk of developing fibrosis, cirrhosis and hepatocellular carcinoma.

Aim of work: to evaluate the occurrence of hepatocellular carcinoma (HCC) in DAA-treated patients with chronic hepatitis $\mathrm{C}$ (CHC).

Patient and Methods: The research involved 500 DAAS-treated patients who had chronic viral hepatitis C. We carried out this retrospective study at Al-Azhar University, Department of Internal Medicine and Hepatology Unit, Ahmed Maher Teaching Hospital. The protocol to the research was accepted by both centers' local ethical committee.

Results: The end of treatment regarding the basic data revealed that HCC patients were significantly older. In spite of the fact that HCC patients in the present study comprised higher frequency of males, the difference between those patients and patients without HCC fell short of statistical significance. In our study, all patients with elevated AFP at the end of treatment developed HCC.

Conclusion: In relation to the various demographic, clinical and laboratory data, hepatocellular carcinoma patients were found to be significantly older when compared with other patients. All chronic hepatitis C patients with elevated alpha-fetoprotein at the end of treatment developed hepatocellular carcinoma.Older HCC-risk patients should be carefully monitored.
\end{abstract}

Keywords: $H C V$; $H C C$; $C H C$; DAAs.

Disclosure: The authors have no financial interest to declare in relation to the content of this article. The Article Processing Charge was paid for by the authors.

Authorship: All authors have a substantial contribution to the article.

\section{INTRODUCTION}

$\mathrm{HCV}$ infection was recognized early on as a significant risk factor for development of HCC, causing around one-third of all HCC cases worldwide, Hepatocellular carcinoma (HCC) is one of the world's leading causes of cancer-related death, and the major histological type of hepatic cancer and the world's second-largest cause of cancer death for more than 500,000 people $^{1}$.

Infection with the hepatitis $\mathrm{C}$ virus is a significant global trigger of hepatocellular carcinoma. Interferon was the main antiviral therapy, which resulted in nearly half of the patients being virally free. The cure rate was significantly increased by new direct-acting antivirals to over $90 \%^{2}$.

The most common primary liver carcinoma is hepatocellular carcinoma (HCC), which makes up for about $80 \%$ of cases. This neoplasia is still ranked 2 nd overall in terms of cancer mortality, despite advances in modern oncology. Regrettably, the rise in HCC incidence is expected to continue in the coming decades.One of the primary causes of mortality and morbidity globally is the hepatitis $\mathrm{C}$ virus (HCV). Hepatocarcinogenesis results from combination of superposing virus specific factors, immunological mechanisms, environmental factors and genetic background factors for persons ${ }^{3}$.

As a risk factor, the therapies regarding hepatitis $\mathrm{C}$ infection were questioned. Some authors pointed out that the risk of developing HCC has been minimized by continued virologic response (SVR) with therapy based on interferon. In contrast, some studies in directacting antiviral (DAA)-treated patients indicate an increased risk of $\mathrm{HCC}^{4}$.

It was also noted that $\mathrm{HCC}$ behavior in patients treated with DAA was more aggressive with respect to portal 
vein thrombosis, malignant lymphadenopathy, and characteristics of $\mathrm{HCC}$ imaging that have influenced ablation chances and response to treatment ${ }^{5}$.

Noteworthy, there was obviously no relation between US research and a few European researches, while Japanese and Egyptian research and other European research demonstrated a higher risk of developing HCC following exposures to DAA. These conflicting findings may be due to changes in geography and ethnicity and discrepancies in design and inclusion criteria between studies ${ }^{6}$.

Purpose of the study to assess the incidence of hepatocellular carcinoma (HCC) in DAA-treated chronic hepatitis $\mathrm{C}(\mathrm{CHC})$ patients.

\section{PATIENT AND METHODS}

This retrospective research was performed at Al-Azhar University, Department of Internal Medicine and Hepatology Unit, Ahmed Maher Teaching Hospital. The protocol to the research was accepted by both centers' local ethical committee.

The study included 500 chronic viral hepatitis C patients who are receiving DAAS. The patients were selected to participate in the study according to the following criteria.

Inclusion criteria:Age >18years and non-cirrhotic patients depending on ultrasound and fibroscan.

Exclusion criteria:Extra-hepatic malignancy except after 2 Years with an interval free with disease.Patients undergoing a liver transplant just prior to study period and patients with severe form of extra-hepatic manifestation.

All the patients underwent to the following:Careful history taking.Extensive clinical examination. Abdominal ultrasonography before therapy and at least 24 weeks after therapy.Laboratory investigations including: The following investigations were done before treat and 12, 24 and 48 weeks after treatment commencement: (i) $\mathrm{HCV}$ RNA quantitativePCR. (ii) Alpha fetoprotein: before therapy and after at least 24 weeks of therapy. (iii) Tests of the liver function (serum albumin, total and direct serum bilirubin, aspartate aminotransferase (AST), alanine aminotransferase (ALT), prothrombin time and INR). (iv) Complete blood count. (v) Fasting blood glucose and HbA1C (in diabetic patients). (vi)Serum creatinine.

Outcome measures:According to current study protocol, the SVR that determines HCV cure as a result of using DAAs in patients was achieved in full by being HCC recorded cases through a 12 month after initiation of treatment regimen.HCC cases were recorded.

Statistical analysis Results of the present study were statistically analyzed using SPSS 25 (IBM, USA). Data were represented as median (interquartile range) or number and percent. Using MannWhitney $U$ test, numerical data were compared while categorical data were compared using Fisher exact test or Chi-square test as necessary. The $\mathrm{P}$ value was deemed statistically significant by less than 0.05 .

\section{RESULTS}

\begin{tabular}{|l|c|c|}
\hline \multicolumn{2}{|l|}{ Age (years) } & $54.0(43.5-61.0)$ \\
\hline \multirow{2}{*}{ Sex } & Male & $284(56.8)$ \\
\cline { 2 - 3 } & Female & $216(43.2)$ \\
\hline BMI $\left(\mathrm{Kg} / \mathrm{m}^{\wedge} 2\right)$ & $29.0(25.3-32.8)$ \\
\hline Albumin $(\mathrm{mg} / \mathrm{dl})$ & $3.8(3.3-4.3)$ \\
\hline \multicolumn{2}{|l|}{ Total bilirubin $(\mathrm{mg} / \mathrm{dl})$} & $0.8(0.6-1.1)$ \\
\hline AST $(\mathrm{IU} / \mathrm{L})$ & $46.0(27.0-69.0)$ \\
\hline ALT $(\mathrm{IU} / \mathrm{L})$ & $40.0(25.0-65.0)$ \\
\hline INR & $1.1(1.0-1.2)$ \\
\hline Hb $(\mathrm{gm} / \mathrm{dl})$ & $13.1(12.4-14.4)$ \\
\hline WBCs $\left(10^{\wedge} 3 / \mathrm{ml}\right)$ & $5.7(4.4-7.5)$ \\
\hline Platelets $\left(10^{\wedge} 3 / \mathrm{ml}\right)$ & $183.0(130.0-241.0)$ \\
\hline FBS $(\mathrm{mg} / \mathrm{dl})$ & $96.0(87.0-108.0)$ \\
\hline Creatinine $(\mathrm{mg} / \mathrm{dl})$ & $0.9(0.7-1.1)$ \\
\hline \multirow{2}{*}{ FIBROSCAN } & F0 & $80(16.0)$ \\
\cline { 2 - 3 } & F1 & $285(57.0)$ \\
\cline { 2 - 3 } & F2 & $135(27.0)$ \\
\hline
\end{tabular}

Table 1: Basic data for the patients studied $(n=500)$. Data expressed as median (Interquartile range) or number and percent

This table shows the basic laboratory data in the studied patients. They had a median (IQR) age of $54.0(43.5-61.0)$ years and comprised 284 males $(56.8 \%)$ and 216 females $(43.2 \%)$.

\begin{tabular}{|c|c|c|c|c|}
\hline & & $\begin{array}{c}\mathrm{HCC} \\
\mathrm{N}=7\end{array}$ & $\begin{array}{c}\text { Other } \\
\text { patients } \\
\mathrm{N}=493\end{array}$ & $\begin{array}{c}\mathbf{P} \\
\text { value }\end{array}$ \\
\hline \multicolumn{2}{|l|}{ Age (years) } & $\begin{array}{c}62.0(56.0- \\
67.0) \\
\end{array}$ & $\begin{array}{c}54.0(43.0- \\
60.5) \\
\end{array}$ & 0.021 \\
\hline \multirow[t]{2}{*}{ Sex } & Male & $6(85.7)$ & $278(56.4)$ & \multirow[t]{2}{*}{0.12} \\
\hline & Female & $1(14.3)$ & $215(43.6)$ & \\
\hline \multicolumn{2}{|c|}{ BMI $\left(\mathrm{Kg} / \mathrm{m}^{\wedge} 2\right)$} & $\begin{array}{c}26.0(24.9- \\
31.5)\end{array}$ & $\begin{array}{c}29.0(25.3- \\
32.8) \\
\end{array}$ & 0.4 \\
\hline \multicolumn{2}{|c|}{ Albumin (mg/dl) } & $3.7(2.9-4.2)$ & $3.8(3.3-4.3)$ & 0.46 \\
\hline \multicolumn{2}{|c|}{$\begin{array}{l}\text { Total bilirubin } \\
\text { (mg/dl) }\end{array}$} & $0.8(0.7-1.5)$ & $0.8(0.6-1.1)$ & 0.4 \\
\hline \multicolumn{2}{|l|}{ AST (IU/L) } & $\begin{array}{c}29.0(27.0- \\
49.0)\end{array}$ & $\begin{array}{c}46.0(27.0- \\
67.0)\end{array}$ & 0.22 \\
\hline \multicolumn{2}{|l|}{ ALT (IU/L) } & $\begin{array}{l}36.0(20.0- \\
58.0)\end{array}$ & $\begin{array}{l}40.0(25.0- \\
59.0) \\
\end{array}$ & 0.58 \\
\hline \multicolumn{2}{|l|}{ INR } & $1.18(1.0-1.22)$ & $1.1(1.0-1.2)$ & 0.91 \\
\hline \multicolumn{2}{|l|}{$\mathbf{H b}(\mathrm{gm} / \mathrm{dl})$} & $\begin{array}{c}13.7(13.0- \\
14.7)\end{array}$ & $\begin{array}{c}13.1(12.5- \\
14.4)\end{array}$ & 0.32 \\
\hline \multicolumn{2}{|c|}{ WBCs $\left(10^{\wedge} 3 / \mathrm{ml}\right)$} & $6.6(6.0-8.1)$ & $5.7(4.4-7.5)$ & 0.32 \\
\hline \multicolumn{2}{|c|}{ Platelets $\left(10^{\wedge} 3 / \mathrm{ml}\right)$} & $\begin{array}{c}241.0(160.0- \\
254.0)\end{array}$ & $\begin{array}{c}182.0(130.0- \\
240.0) \\
\end{array}$ & 0.33 \\
\hline \multicolumn{2}{|l|}{ FBS $(\mathrm{mg} / \mathrm{dl})$} & $\begin{array}{c}93.0(84.0- \\
100.0) \\
\end{array}$ & $\begin{array}{c}97.0(87.0- \\
110.0) \\
\end{array}$ & 0.29 \\
\hline \multicolumn{2}{|c|}{ Creatinine (mg/dl) } & $0.7(0.55-1.3)$ & $0.9(0.7-1.1)$ & 0.31 \\
\hline \multirow{3}{*}{ FIBROSCAN } & Fo & $1(14.3)$ & $79(16.0)$ & \multirow{3}{*}{0.024} \\
\hline & F1 & $1(14.3)$ & $284(57.6)$ & \\
\hline & F2 & $5(71.4)$ & $130(26.4)$ & \\
\hline
\end{tabular}

Table 2: Comparison of HCC patients and patients with no basic data.

This table shows that HCC patients are significantly older and had significantly higher frequency of F2 Metavir stage when compared with patients without HCC. 


\begin{tabular}{|c|c|c|c|}
\hline & $\begin{array}{c}\mathrm{HCC} \\
\mathrm{N}=7\end{array}$ & $\begin{array}{c}\text { Other } \\
\text { patients } \\
\mathrm{N}=493\end{array}$ & $\begin{array}{c}P \\
\text { value }\end{array}$ \\
\hline $\begin{array}{l}\text { Albumin } \\
(\mathrm{mg} / \mathrm{dl})\end{array}$ & $3.1(2.4-4.0)$ & $3.5(3.1-4.0)$ & 0.16 \\
\hline $\begin{array}{l}\text { Total bilirubin } \\
(\mathrm{mg} / \mathrm{dl})\end{array}$ & $1.4(0.6-1.8)$ & $0.9(0.7-1.1)$ & 0.17 \\
\hline AST (IU/L) & $\begin{array}{l}24.0(18.0- \\
30.0)\end{array}$ & $\begin{array}{c}24.0(19.0- \\
34.0)\end{array}$ & 0.72 \\
\hline ALT (IU/L) & $\begin{array}{l}18.0(15.0- \\
27.0)\end{array}$ & $\begin{array}{c}21.0(16.0- \\
27.0)\end{array}$ & 0.56 \\
\hline INR & $\begin{array}{c}1.0(1.0- \\
1.23)\end{array}$ & $1.1(1.0-1.2)$ & 0.33 \\
\hline Hb $(\mathrm{gm} / \mathrm{dl})$ & $\begin{array}{c}12.0(11.5- \\
14.7)\end{array}$ & $\begin{array}{c}11.5(10.6- \\
12.8)\end{array}$ & 0.12 \\
\hline $\begin{array}{l}\text { WBCs } \\
\left(10^{\wedge} 3 / \mathrm{ml}\right)\end{array}$ & $5.8(4.3-6.7)$ & $5.8(4.9-7.6)$ & 0.71 \\
\hline $\begin{array}{l}\text { Platelets } \\
\left(10^{\wedge} 3 / \mathrm{ml}\right)\end{array}$ & $\begin{array}{c}236.0(181.0 \\
-266.0) \\
\end{array}$ & $\begin{array}{c}193.0(155.0- \\
248.0) \\
\end{array}$ & 0.17 \\
\hline FBS $(\mathrm{mg} / \mathrm{dl})$ & $\begin{array}{c}95.0(94.0 \text { - } \\
118.0) \\
\end{array}$ & $\begin{array}{c}99.0(90.0- \\
112.0)\end{array}$ & 0.73 \\
\hline $\begin{array}{l}\text { Creatinine } \\
(\mathrm{mg} / \mathrm{dl})\end{array}$ & $\begin{array}{c}0.9(0.7- \\
1.1)\end{array}$ & $0.9(0.8-1.1)$ & 0.67 \\
\hline SVR & $7(100.0)$ & 318 (64.5) & 0.15 \\
\hline
\end{tabular}

Table (3): Comparison of HCC patients and patients with no clinical data at 12 weeks.

This table shows no statistically significant differences between HCC patients and patients with no laboratory data at 12 weeks of treatment.

\begin{tabular}{|c|c|c|c|}
\hline & $\begin{array}{l}\text { HCC } \\
\mathrm{N}=7\end{array}$ & $\begin{array}{l}\text { Other } \\
\text { patients } \\
\mathrm{N}=493\end{array}$ & $\begin{array}{l}P \\
\text { value }\end{array}$ \\
\hline Albumin (mg/dl) & $\begin{array}{l}3.0(2.8- \\
4.0)\end{array}$ & $\begin{array}{l}3.9(3.2- \\
4.0)\end{array}$ & 0.11 \\
\hline $\begin{array}{c}\text { Total bilirubin } \\
(\mathrm{mg} / \mathrm{dl})\end{array}$ & $\begin{array}{l}1.0(0.6- \\
1.6)\end{array}$ & $\begin{array}{l}0.9(0.7- \\
1.0)\end{array}$ & 0.3 \\
\hline AST (IU/L) & $\begin{array}{l}17.0(16.0- \\
26.0)\end{array}$ & $\begin{array}{l}20.0(16.0- \\
24.0)\end{array}$ & 0.35 \\
\hline ALT (IU/L) & $\begin{array}{l}13.0(7.0- \\
27.0)\end{array}$ & $\begin{array}{l}20.0(15.0- \\
24.0)\end{array}$ & 0.13 \\
\hline INR & $\begin{array}{l}1.0(1.0- \\
1.0)\end{array}$ & $\begin{array}{l}1.0(1.0- \\
1.1)\end{array}$ & 0.17 \\
\hline $\mathbf{H b}(\mathrm{gm} / \mathrm{dl})$ & $\begin{array}{l}11.5(10.6- \\
14.2)\end{array}$ & $\begin{array}{l}11.0(10.0- \\
12.0)\end{array}$ & 0.32 \\
\hline WBCs $\left(10^{\wedge} 3 / \mathrm{ml}\right)$ & $\begin{array}{l}5.0(4.1- \\
6.0)\end{array}$ & $\begin{array}{l}5.4(4.7- \\
7.0)\end{array}$ & 0.37 \\
\hline Platelets $\left(10^{\wedge} 3 / \mathrm{ml}\right)$ & $\begin{array}{l}189.0 \\
(150.0- \\
220.0)\end{array}$ & $\begin{array}{l}180.0 \\
(149.0- \\
210.5)\end{array}$ & 0.72 \\
\hline FBS $(\mathrm{mg} / \mathrm{dl})$ & $\begin{array}{l}101.0(90.0 \\
-102.0)\end{array}$ & $\begin{array}{l}99.0(90.0- \\
104.0)\end{array}$ & 0.97 \\
\hline Creatinine $(\mathrm{mg} / \mathrm{dl})$ & $\begin{array}{l}1.0(0.9- \\
1.2)\end{array}$ & $\begin{array}{l}1.0(0.9- \\
1.1)\end{array}$ & 0.37 \\
\hline SVR & $7(100.0)$ & $493(100.0)$ & NA \\
\hline
\end{tabular}

Table 4: Comparison of HCC patients and patients with no clinical data at 24 weeks.

This table shows no statistically significant differences between HCC patients and patients with no laboratory data at 24 weeks of treatment.

\begin{tabular}{|c|c|c|c|}
\hline & $\begin{array}{l}\mathrm{HCC} \\
\mathrm{N}=7\end{array}$ & $\begin{array}{l}\text { Other } \\
\text { patients } \\
\mathrm{N}=493\end{array}$ & $\begin{array}{l}\mathbf{P} \\
\text { value }\end{array}$ \\
\hline $\operatorname{Albumin}(\mathrm{mg} / \mathrm{dl})$ & $3.1(2.8-3.9)$ & $\begin{array}{c}3.8(3.1- \\
4.0)\end{array}$ & 0.1 \\
\hline $\begin{array}{c}\text { Total bilirubin } \\
(\mathrm{mg} / \mathrm{dl})\end{array}$ & $1.0(0.7-1.6)$ & $\begin{array}{c}0.8(0.6- \\
1.0)\end{array}$ & 0.06 \\
\hline AST (IU/L) & $\begin{array}{c}15.0(14.0- \\
20.0)\end{array}$ & $\begin{array}{c}18.0(15.0 \\
-21.0) \\
\end{array}$ & 0.21 \\
\hline ALT (IU/L) & $\begin{array}{c}13.0(12.0- \\
19.0) \\
\end{array}$ & $\begin{array}{c}17.0(12.0 \\
-21.0) \\
\end{array}$ & 0.11 \\
\hline INR & $1.1(1.06-1.5)$ & $\begin{array}{c}1.05(1.0- \\
1.2) \\
\end{array}$ & 0.14 \\
\hline $\mathbf{H b}(\mathrm{gm} / \mathrm{dl})$ & $\begin{array}{c}14.1(13.3- \\
14.5)\end{array}$ & $\begin{array}{c}13.8(13.0 \\
-14.7) \\
\end{array}$ & 0.63 \\
\hline WBCs $\left(10^{\wedge} 3 / \mathrm{ml}\right)$ & $6.3(3.7-9.0)$ & $\begin{array}{c}6.4(5.3- \\
8.4) \\
\end{array}$ & 0.89 \\
\hline Platelets $\left(10^{\wedge} 3 / \mathrm{ml}\right)$ & $\begin{array}{c}194.0(104.0- \\
220.0)\end{array}$ & $\begin{array}{c}195.0 \\
(174.0- \\
231.0)\end{array}$ & 0.58 \\
\hline FBS $(\mathrm{mg} / \mathrm{dl})$ & $\begin{array}{c}94.0(89.0- \\
101.0)\end{array}$ & $\begin{array}{c}100.0(91.0 \\
-110.0) \\
\end{array}$ & 0.33 \\
\hline Creatinine $(\mathrm{mg} / \mathrm{dl})$ & $1.0(0.9-1.0)$ & $\begin{array}{c}1.0(0.9- \\
1.1) \\
\end{array}$ & 0.53 \\
\hline \begin{tabular}{|c|} 
Alpha- \\
fetoprotein(AFP) \\
+ ve
\end{tabular} & $7(100.0)$ & - & $\begin{array}{l}< \\
0.001\end{array}$ \\
\hline SVR & $7(100.0)$ & $\begin{array}{c}493 \\
(100.0) \\
\end{array}$ & NA \\
\hline
\end{tabular}

Table 5: Comparison of HCC patients and patients with no clinical data at 48 weeks.

This table shows that HCC patients had significantly higher frequency of APP

+ve cases after therapy ends.

\section{DISCUSSION}

The study aimed to evaluate the prevalence of HCC development in non-cirrhotic patients who are receiving DAA. The study recruited 500 patients with HCC subjected to DAA therapy. Patients were followed after achieving SVR 48 weeks following start of treatment. The HCC diagnosis was basedupon the radiological and Laboratory data.

In this study, 7 patients out of $500(1.4 \%)$ acquired HCC. In comparison, the Egyptian study of Lashen et al. ${ }^{7}$ in which the authors retrospectively analyzed results of 392 F3-4 fibrosis patients and DAAtreated cirrhosis. In $7.6 \%$ of naive patients, De novo HCC occurred while recurrence occurred in $28 \%$ of previous HCC patients. This high prevalence of $\mathrm{HCC}$ in an Egyptian population may reflect the role of liver cirrhosis as pathological correlate with development of HCC in patients treated with DAA with no prior history of HCC. However, other studies conducted worldwide revealed inconsistent results. In an Italian study including a total of 3,917 
HCV patients treated with DAAs ,55 patients developed $\mathrm{HCC}$ in the first year making an incidence of $1.4 \%$. However, it should be noted this study included only cirrhotic patients ${ }^{8}$.

In the Japanese study of Ogawa et al. ${ }^{9}$ who evaluated the short- term risk of HCC SVR patients with DAAs, and those with cirrhosis or prior HCC, the study found that HCC developed in $46(2.7 \%)$ patients during time of follow-up (median: 17 months). Importantly, the authors, in accordance with our conclusions, reported that de novo HCC was registered in $0.4 \%$ of non-cirrhotic patients in comparison to $4.9 \%$ of the cirrhotic patients.

Moreover, in the study of Kuftinec et al. ${ }^{10}$ on 150 DAA-treated patients with HCV-cirrhosis, seven patients developed HCC de novo that did not vary by $3 \%$ from historical rates. The study noted substantially higher HCC rates in patients with decompensated cirrhosis.

For another Japanese study, a total of 1,174 chronic hepatitis $\mathrm{C}$ virus patients were treated with DAA.In 33 instances, HCC developed over median observation duration of 537 days.HCC incidence was $1.9 \%, 3.2 \%$, and $4.1 \%$ respectively at $1,1.5$, and 2 years after the completion of DAA therapy ${ }^{11}$. On the other hand, the study of Yoo et al. ${ }^{12}$ on $574 \mathrm{HCV}$ patients receiving direct-acting antiviral therapy for at least 24 weeks, found that the cumulative HCC incidence was $0.47 \%$. Unfortunately, these two studies didn't report the percentage of cirrhosis patients according to the Metavirscore.Multiple mechanisms for the occurrence of HCC and rapid immune changes have also been documented, includes cytokines and chemokines during and following DAA therapy ${ }^{13}$.

The most potential mechanisms include the following points:

Immune cell dysfunction: Initial data regarding the T-cell function were published in 2014 during and after direct-acting antiviral therapy ${ }^{14}$.In 51 previously untreated and chronically infected patients receiving DAAS therapy, treatment the researchers analyzed virus-specific CD8+ T cells and in patients receiving SVR within 4 weeks of treatment, the frequency of $\mathrm{HCV}$-specific $\mathrm{CD} 8+\mathrm{T}$ cells increased significantly, whereas there are no alterations in patients with therapeutic failure were observed. Result of infection with $\mathrm{HCV}$ revealed reversible immune dysfunction and that even short treatment was able to restore immune capacity with novel DAAs.

Change in immune cytokine network: Two studies recorded a rapid decrease in IL-18 serum early after beginning DAA therapy Spaan et al. ${ }^{15}$ and Carlin et al. ${ }^{16}$ that was not confirmed by others Ning et al. ${ }^{17}$.

Activation of angiogenesis: Faillaci et al. ${ }^{18}$, analyzed levels of serum liver angiopoietin-2 and VEGF (vascular endothelial growth factor) in 242 DAAtreated patients and the DAA-mediated increase in VEGF and angiopoietin-2 resulted in an elevated risk of $\mathrm{HCC}$ occurring during antiviral treatment.

In this study, comparison between HCC patients and patients without at the end of treatment regarding the basic data revealed that HCC patients were significantly older. This finding is consistent with the study of Ogawa et al. ${ }^{9}$ who noted that patients with HCV who developed de novo HCC were substantially older than those without it.

In spite of the fact that HCC patients in the present study comprised higher frequency of males, the difference between those patients and patients without HCC fell short of statistical significance. In contrast, the study of Liu et al. ${ }^{19}$ identified male sex as a significant risk factor for developing HCC following DAA drugs.

In our study, in accordance with Yoo et al's study, all patients with alpha-fetoprotein elevation (AFP) developed $\mathrm{HCC}$ at the end of treatment ${ }^{12}$. In their work on $574 \mathrm{HCV}$ patients treated with DAA, multivariate analysis revealed that the levels of alpha-fetoprotein $>9.5 \mathrm{ng} / \mathrm{mL}$ was the only independent early development risk factor for HCC when treatment ended.

\section{CONCLUSION}

Among the studied patients, 7 patents out of 500 (1.4 $\%)$ acquired hepatocellular carcinoma after 48 weeks of treatment as confirmed by the imaging and laboratory studies.

In relation to the various demographic, clinical and laboratory data, hepatocellular carcinoma patients were found to be significantly older when compared with other patients.

All chronic hepatitis $\mathrm{C}$ patients with elevated alphafetoprotein at the end of treatment developed hepatocellular carcinoma.

\section{REFERENCES}

1. Hoshida Y, Fuchs BC, Bardeesy N, et al.Pathogenesis and prevention of hepatitis $\mathrm{C}$ virusinduced hepatocellular carcinoma. $J$ Hepatol., 2014;61(1):79-90.

2. Baumert TF, Jühling F, Ono A, et al. Hepatitis Crelated hepatocellular carcinoma in the era of new generation antivirals. BMC Med., 2017;15(1):52-5.

3. Ružić M, Pellicano R, Fabri M, et al. Hepatitis C virus-induced hepatocellular carcinoma: a narrative review. Panminerva Med. 2018;60(4):185-91.

4. Chinchilla-López P, Qi X, Yoshida EM, et al. The Direct-Acting Antivirals for Hepatitis C Virus and the Risk for Hepatocellular Carcinoma. Ann Hepatol., 2017;16(3):328-30.

5. Abdelaziz AO, Nabil MM, Abdelmaksoud AH, et al. Tumor behavior of hepatocellular carcinoma after hepatitis $\mathrm{C}$ treatment by direct-acting antivirals: comparative analysis with non-direct-acting antivirals-treated patients. Eur $J$ Gastroenterol Hepatol., 2019;31(1):75-9. 
6. El Kassas M, Elbaz T, Salaheldin M, et al. Impact of treating chronic hepatitis $\mathrm{C}$ infection with directacting antivirals on the risk of hepatocellular carcinoma: The debate continues - A mini-review. $J$ Adv Res., 2019;17:43-8.

7. Lashen SA, Shamseya MM and Madkour MA. Hepatocellular Carcinoma Occurrence/Recurrence after Direct-Acting Antivirals for Hepatitis C in Egyptian Cohort: Single-Center Experience. Dig Dis., 2019; 19:1-10.

8. Romano A, Angeli P, Piovesan S, et al. Newly diagnosed hepatocellular carcinoma in patients with advanced hepatitis $\mathrm{C}$ treated with DAAs: a prospective population study. J Hepatol., 2018; 69:345-52.

9. Ogawa E, Furusyo N, Nomura H, et al. Short-term risk of hepatocellular carcinoma after hepatitis $\mathrm{C}$ virus eradication following direct-acting anti-viral treatment. Aliment Pharmacol Ther., 2018; 47(1):104-13.

10. Kuftinec G, Loehfelm T, Corwin M, et al.De novo hepatocellular carcinoma occurrence in hepatitis $\mathrm{C}$ cirrhotics treated with direct-acting antiviral agents. Hepat Oncol., 2018;5(1):6-9.

11. Watanabe T, Tokumoto Y, Joko K, et al. Predictors of hepatocellular carcinoma occurrence after directacting antiviral therapy in patients with hepatitis C virus infection. Hepatol Res., 2019;49(2):136-46.

12. Yoo SH, Kwon JH, Nam SW, et al. Early development of de novo hepatocellular carcinoma after direct-acting agent therapy: Comparison with pegylated interferon-based therapy in chronic hepatitis C patients. J Viral Hepat., 2018;25(10):1189-96.
13. Sasaki R, Kanda T, Kato N, et al. Hepatitis C virusassociated hepatocellular carcinoma after sustained virologic response. World J Hepatol., 2018;10(12):898-906.

14. Martin B, Hennecke N, Lohmann V, et al. Restoration of HCVspecific CD8+ T cell function by interferon-free therapy. J Hepatol., 2014; 61:538-43.

15. Spaan M, Van Oord G, Kreefft K, et al. Immunological analysis during interferon-free therapy for chronic Hepatitis $\mathrm{C}$ virus infection reveals modulation of the natural killer cell compartment. Journal of Infectious Diseases, 2016;213(2):216-23.

16. Carlin AF, Aristizabal P, Song Q, et al. Temporal dynamics of inflammatory cytokines/chemokines during sofosbuvir and ribavirin therapy for genotype 2 and 3 hepatitis $\mathrm{C}$ infection. Hepatology, 2015;62(4):1047-58.

17. Ning G, Li Y, Chen Y, et al. Dynamic Changes of the Frequency of Classic and Inflammatory Monocytes Subsets and Natural Killer Cells in Chronic Hepatitis C Patients Treated by DirectActing Antiviral Agents. Can J Gastroenterol Hepatol., 2017; 2017: 3612403.

18. Faillaci F, Marzi L, Critelli R, et al. Liver Angiopoietin-2 Is a Key Predictor of De Novo or Recurrent Hepatocellular Cancer After Hepatitis C Virus Direct-Acting Antivirals.Hepatology, 2018; 68(3):1010-24.

19. Liu P, Xie S, Hu S, et al. Age-specific sex difference in the incidence of hepatocellular carcinoma in the United States. Oncotarget., 2017; 8(40): 68131-7. 